No vomiting during the night; enemata given sixhourly; child grew drowsy during latter part of day. 11th: Vomited again at 10 A.M. Takes well of sodium bicarbonate in water. Is fretful. 12th : Vomited once this morning. Still on enemata every six hours, as well as orange juice and sodium bicarbonate by mouth. Put on bovril. 13th: Vomited twice this morning; very torpid; sodium bicarbonate increased; one drachm four-hourly by rectum. whilst the bread-and-butter and milk-pudding was sprinkled with it; making about $1 \frac{1}{2}$ oz. in the 24 hours. Vomited once on the 14th and on the 15th ; after that date no further nausea, child taking food well and got quite bright mentally. 18th: Enemata omitted, but sodium bicarbonate still added to food. 19th: Sodium bicarbonate reduced to half an ounce in 24 hours. 20th: Very little colour with ferric chloride. 21st: Urine gives no colour with ferric chloride and patient put on fish diet. 28th: Swab gave Hoffmann's bacillus. Jan. 6th: Ready for discharge.

Fortunately the odour of the romit was marked, or else the sickness might have been thought to be of vagal origin. The torpid condition of the child was not, however, that associated with the latter, and appeared rather a characteristic symptom; it improved rapidly with the increased doses of sodium bicarbonate; this latter was reduced as soon as effervescence was given with ferric chloride and the urine.

Great Yarmouth.

\section{NOTES OF A CASE OF EXTENSIVE SURGLCAL EMPHYSEMA.}

By E. Norman Butler, M.R.C.S. Eng., L.R.C.P. LOND.

A CASE of surgical emphysema presenting features that seem worth recording recently came under my notice.

The patient, an Indian, was injured in a railway accident wherein a portion of a train fell over an embankment some 40 feet high, and was found lying with a heavy baulk of timber across his chest. The accident occurred about 9.30 P.M. I first saw him at about 12.30 A.M., when owing to the difficulty of the circumstances and the numbers of others injured, an exhaustive examination was not possible. He then showed enormous swelling of the face, neck, and trunk generally, the crepitus of surgical emphysema being everywhere obtainable. There being no obvious immediate treatment called for, I left him in order that I might attend to others whose injuries were more amenable to first aid, and I cannot say if the limbs were at that time involved.

$\mathrm{He}$ was next seen some six hours after, when the injured had been conveyed to hospital, and I noticed that while awaiting his turn to be carried into the hospital he was unconcernedly smoking a cigarette. He showed little respiratory distress and talked intelligently. By this time the emphysema involved the whole trunk, the neck, face, whole of the scalp, the arms as far as the wrists, and the legs to just below the knees. Pain was complained of on pressure over the lower ribs of the left side, though no actual fracture of ribs could be made out owing to the condition of the subcutaneous tissues. There was no external wound. Dr. Lucius Nichols, who kindly assisted me to deal with the injured, expressed his opinion that further entry of air into the tissues might be prevented if an attempt was made to close the entry to the pleuræ, but while preparations were being made to do this the patient suddenly exhibited most extreme dyspnoea and the pulse became impalpable, and he died in two or three minutes from the outset of these symptoms.

At the post-mortem examination the seventh rib on the left side was found to be fractured and a fragment of bone had penetrated the lung for a distance of one or one and a half inches. The lung showed no sign of collapse, nor was there any pneumothorax.

The points of interest exhibited by this case are I think: (1) The great extent of the surgical emphysema; (2) the rapidity of its spread; and (3) the fact that death was seemingly due to sudden syncope rather than asphyxia, as evidenced by the comparative absence of dyspnœa until within a few moments of death.

Magadi Junction, British East Africa.

\section{Settroical Sorteties.}

\section{MEDICAL SOCIETY OF LONDON.}

\section{Operative Treatment of Tumours of the Cacum and Colon.}

A MEETING of this society was held on Oct. 26th, Sir J. Brasd-Sutron, the President, being in the chair. A discussion was held on the Operative Treatment of Tumours of the Cæcum and Colon, especially in relation to immediate resection, colostomy combined with secondary resection, and short circuiting.

Mr. H. J. WARING opened the discussion from the point of view of malignant disease of the cæcum. He said that malignant disease of the creum in the majority of cases was a columnar-celled carcinoma, usually of the exuberant type, forming a mass protruding into the lumen of the cæcum, or less commonly an annular ring of new growth, scirrhous in character, and tending at a comparatively early stage to give rise to obstruction in the intestinal canal. Generally the exuberant type of growth commenced in the region of the ileocæcal valve, whilst the annular type was more common where the cæcum passed into the ascending colon. Occasionally, however, a constricting growth might be met with on the proximal side of the ileocacal valve, in which case it would be found to commence in the mucous membrane of the most distal part of the ileum and to involve the cæcum by direct extension. A small proportion of neoplasms of the cæcum were sarcomata, and these usually commenced in the wall of the cæcum beyond the ileocæcal valve. He exhibited specimens of these different forms of growth. Included with the cæcum was, he supposed, the vermiform process. True carcinoma of this process in his experience was extremely rare. Some years ago he investigated 600 consecu. tive cases of disease of the vermiform process, and no single case was definitely shown to be true carcinoma. In the museum of St. Bartholomew's Hospital there were two specimens which had been called carcinoma. They, however, histologically presented more the charaoteristics of endotheliomata. They were removed from patients aged 27 and 29 respectively. The two specimens were exhibited, and in addition a microscopical preparation of a similar condition. When compared with carcinoma in other parts of the body, carcinoma of the cæcum (and other portions of the colon) was, on the whole, he thought, less malignant, the rate of growth of the neoplasm being slower, infection of lymph vessels and glands later, whilst visceral secondary growths only appeared when the affection had existed for a considerable period. This diminished malignancy was especially the case when the neoplasm was of the adeno-carcinomatous type and extended into the lumen of the bowel as a cauliflower-like protuberance. Sarcoma, on the contrary, appeared to be quite as malignant as when occurring in other parts. Concerning frequency he found that during the years 1909-13 107 cases of malignant disease of the large intestine (excluding the rectum) were admitted into the surgical wards of St. Bartholomew's Hospital, and 